\title{
Loss Compensation Practices in International Sales
}

\author{
Alireza Azadi Kalkoshki ${ }^{1}$ \& Mohsen Hosein Abadi $^{1}$ \\ ${ }^{1}$ FEBIT International Law Office \\ Correspondence: Mohsen Hosein Abadi, FEBIT International Law Office. E-mail: f.o.20@febitmail.com
}

Received: May 10, 2017

doi:10.5539/jpl.v10n4p118
Accepted: June 10, 2017 Online Published: August 30, 2017

URL: https://doi.org/10.5539/jpl.v10n4p118

\begin{abstract}
By concluding any sale, its results works are swiped salesperson and the buyer. The origin of these commitments and traces should be considered the will rule in the conclusion. The contract parties are obliged to do something or refuse to take the current. The commitments of the parties to perform the contract content is interpreted "contractual liability". Contract terms and principles and its loss compensation remedies in international sales conventions of goods and rights of Iran and some countries such as France, Egypt, Lebanon don't have the greatest difference and hasn't seen any major hurdle in the way of Iran to join the Convention. Because of the methods of loss calendar and the conditions of its time and site setting in the Convention is workable in the Rights of Iran. But some of the ways to compensate for damages caused by contract defects that are not predicted in the International Convention such as paying the interest are not accepted in Iranian laws. Compensation for damages arising from the breach of contractual obligations needs to be injured in a position that if the obligation was done under the contract, have been fixed in that situation. In the international commercial contracts, principles of the private law unification institute, this attitude is acceptable and based on this, the theory of full compensation of damage is accepted. In this article, collecting information is done using the library method and going directly to the applied resources and obtained data have been studied using analytical-description method of loss compensation.
\end{abstract}

Keywords: loss compensation, international sales, international sales contracts convention of the goods, principles of trade contracts

\section{Introduction}

Trade is one of the most common and important forms of the relations of states and nations with each other in which the cultural, social and political exchanges are taken place. So no vain that the international community has begun one of the first efforts towards integration and legal unity of this area. Up to now, many countries have joined to this convention and the new international economic order with forming the World Trade Organization and membership of many countries in it has become stronger. On the other hand it should be noted that although each country based on its historical, cultural, social, economic, political and geographical characteristics has an independent legal system that is more or less different with other legal systems in other countries, but today, an important part of these differences with transformation and growth of human knowledge, technology and vicinity of people to each other and spreading communications equipment increasingly seems unjustified, inappropriate and harmful and most of them can be removed without harming the cultural authenticity and historical identity of a nation. Warranty of commitment contravention, particularly loss compensation, is of practical issues in contract laws. The main question of this article is regarding the scope of loss compensation and saying this matter that loss compensation limit is from the viewpoint of trade contracts, the International sale contracts convention of the goods and Iran's rights and what losses as a result of contract breach is exigible?

Our hypothesis in this paper is the need for full compensation of any losses and damages resulting from the strengthening of the expected benefits from the contract. In this paper, after a brief review of the need for loss compensation and its conditions, we pay for all aspects of the theory of full loss compensation.

\section{The Principle of Loss Compensation and Breach of Contractual Obligations}

\subsection{Being Certain and Definitive of the Damage}

Compensable damage, is the damage that it's happening is ascertained. This description is rational and obvious and its verification requires no theoretical argument. It is clear that what is become certain its entity and also is not exist in human vision cannot be owned by an individual or a legislator and will be under the responsibility. If 
the breach of contract by one party to the contract leads to damage to the other party, he has the right to claim damages and someone who breach the contract compensates usually through donations or through other compensation, such as the obligation to fulfill the obligation, to reduce the price that may be used in addition to monetary damages properly. This method of compensation, in practice is the most important available means of compensation. Therefore, it is also mentioned as the main purpose of civil liability in relation to the injured and preventing future damage, the elimination of the rights of the plaintiff, quenching the anger and reducing and irritation are enumerated as other purposes of civil liability (Treitel, 2003).

\subsection{Conditions of Fulfillment of Contractual Liability}

The provisions of the necessity in the contracts define that the parties to the provisions of the covenant and its commitment to act with inaction or surrender sales or price, or general "to execute anything where is stipulated " (Article 220 of the civil law) must be loyal. If one of the parties don't act to his commitment and behave contrary to his commitment content, is responsible in front of his action. This responsibility arising from the contract is concluded the so-called "contractual liability" (Safaei et al, 2013).

Contractual liability is known Party claimed responsibility that not to perform the contract, namely do not act the obligations arising from the contract properly. Under this definition, the need to compensate for losses is inadmissibility that obligee has suffered due to non-fulfillment of commitment by pledging. The source of this requirement for the undue loss compensate can be known contract, custom or law. The argument is that when this responsibility can be fulfilled and what are the conditions for investigating this requirement?

In International Sale Convention of Goods acted in 1980, contractual liability is mentioned in cases 74 to 77 and other articles and in Iranian civil law 221 refers to the responsibility.

\subsubsection{Contractual Liability in the Convention and the Conditions for Its Implementation}

In Convention, no particular article is expressed for contractual liability; but the general conditions a claim for damages was among those to express conditions of responsibility attention to engaged can be achieved among the cases that is presented for expression of the creation conditions of loss claim right. In other words, when the obligee will have the right to claim damages that responsibility is committed to engaged and receipting the loss without responsibility to engaged is meaningless.

In the Convention, when an engaged don't commit to the provisions of his commitment and don't act to the provisions of his contract, regardless of breach of contract, it causes responsibility attention to engaged. Convention assumes the relation between the act of engaged and not to make the contract and if the provisions of the contract isn't act, first and foremost, engaged is responsible and responsive to the lack of commitment. As the burden of proof rests with engaged, he can appeal the reason, disclaims this responsibility from him and refer to the foreign agent or a third party. Creation conditions of this responsibility in the international sales convention is as following:

First: entrance of damage to the obligee

Article 74 of the Convention provides:

"Damages arising from breach of contract by one party, is the amount equal to the losses that the other party is incurred by the violation."

From this expression can be concluded that responsibility is created when as a result of the breach, the damage inflicted to the engaged and responsibility essentially without prejudicing is unimaginable. These losses must be ascertained. The losses include the loss (deterioration and destruction of what was available) and non-profit (deprivation from the acquisition of property increase).

The losses incurred by the obligee must be proven, then obliged to indemnify from engaged. According to Article 5, the Convention covers only monetary losses and physical or moral losses are not covered by the Convention. Such losses should be charged by reference to the conflict rules of involved countries (Katouzian, 2011b).

Second, the loss should have been predictable.

Article 74 "... the damage couldn't overrun from the amount of losses that adversative at the time of conclusion of the contract were aware or should be aware... anticipated or should have had anticipated." This statement suggests that the adversative of the contract is responsible for the damages that at the time of conclusion of the contract as a result of breach of contract has been foreseeable for him.

According to commentators, the circle of Article 74 of the Convention was limited to the loss predictability at the 
time of contract conclusion, and predictability that creates later, under Article 74 of the Convention, doesn't have legal effect. But this opinion seems to be criticized; because even though the losses may be predictable at the time of the contract conclusion, but it may be predictable after the contract conclusion and before the loss, and even in many cases be preventable and should not be ignored. Damages for breach of contract imposed on the obligee must be compensated and lack of compensation is inadmissibility loss that must not impose to bona fide obligee.

Based on stipulation of the above-mentioned document, time of the damage prediction is the time of contract conclusion and the engaged breach of contract isn't responsible for the damage that is not predictable in terms of typical and practical at the time of contract conclusion, although he can predict it later (Huet, 1996).

The use of the phrase "predicted or should have predicted" in the International Sale Contract Convention of Goods and clearer interpretation "had predicted or could have been predicted" in the principles of international commercial contracts suggests that the prediction criteria for breach of contract damages in the first stage is personal and then typical meaning that an adversative of the contract, predicted the damage arising from the breach of contract himself or routine persons in conventional affairs and special circumstances of contract predict damages for breach of contract. On this basis, the claimant does not have to prove the loss prediction caused by the adversative of obligations, but this amount proven, the conventional people in such circumstances, predict the damage caused by the breach of contract, there is possibility to claim damages for the lost (Badini, 2005).

Third, there must be a causal relationship between the breach of contract and loss

This condition is implicit in Article 74 of the Convention, where it said: "... damages arising from breach of contract is ..." it is obvious that each individual is responsible for his actions and so engaged is responsible when damage is as a result of contract breach. from the perspective of the Convention, no different that the loss is direct or indirect effect contract breach.

Of principles of the international commercial contracts also this condition is used. Paragraph 1 of Article 2-4-7, these principles are definite, "the lost due to imposing the damages caused by non-performance, is entitled to full compensation." In addition to being in this regulation on the principle of the injured party is emphasized to receive full compensation for the damage and losses incurred from a breach of contract, the phrase "damage resulting from non-performance" is used from a causal relationship between the lack of implementation and losses.

According to the sense of articles 79 and 80 of the convention, regardless of the contract breach is considered a fault and in other word: with contract breach, responsibility assumption is created for the adversative and if adversative proves the existing of the external events according to Article 79, can escape from the consequences of this responsibility (Barikloo, 2008).

\section{Conditions to Claim Damages}

Breach of contracts in the international sale contracts convention of Goods, is the main condition for compensation claims and breach of contract. In items 45 and 61 of this convention, default of seller and buyer to perform any of their obligations under the contract or the convention is considered a violation of a contractual obligation.

In the principles of international trade contracts, breach of commitment, is explain to non-performance of commitment and in Article 7-1-1 of this document, "non-performance is the fault of one hand in the implementation of any of his contractual obligations that include defective or with a delay performance."

So a breach of contract occurs when one side without being legally be excused; in doing what he has been responsible fails based on the contract, generally refuse to implement the commitment; incomplete the commitment; doesn't perform the quantity or quality agreed or doesn't fulfill it in an appointed place or time. Breach of any of the above forms, according to Article 7-4-1 of international commercial contracts "towards the injured, the right to claim damages exclusively or in conjunction with any other compensation" (Honnold, 1991).

Iranian law also emphasizes on the right to claim damages resulting from a breach of contractual obligations. Including Article 221 of the Civil law expresses, "If someone oblige to do something or oblige to refrain from doing something while the violation is responsible for damage of another party..." In addition, Article 227 and 228 of this act and Article 515 of the Civil Procedure law stipulates this right.

\section{Specific Description of Irreparable Damage}

Characteristics of international trade and its requirements such as the concentration of wealth and its rapid and 
easy exchange and prompt resolve and without the complexity of disputes and lawsuits trade have led provide specific explanations in the international sale convention of goods for exigible damages under this Convention.

\subsection{Loss Should Be Financial Not Physical}

According to article 5 of the Convention, physical damage and its compensation is not under the provisions of the convention only covers property damage. Regulation of this article actually explains and describes the logic of article 4 of the convention that according to it, the convention only governs the sale contract conclusion and the rights and obligations of the seller and the buyer. According to this matter, including bodily injuries and death of people, including buyer caused by the product is outside the scope of the convention and article 5 stipulates it.

Convention excludes this provision in particular the physical damage caused by the use of defective or dangerous goods. All claims for bodily injury arising from the use of such goods in accordance with the competent national law is resolved. In explaining the philosophy of this exception can be said that on the one hand, the rules related to liability arising from the act of production in each country are generally related to public order.

\subsection{Losses Must Be Material Not Spiritual}

This is not stipulated in convention, but it can be concluded according to the logic criteria of article 4 of the Convention (just rights and obligations arising under the contract of sale are subject to the Convention), prediction of article 5 or its concept.

Primarily investigation of the spiritual damage caused by the harm arrival to spiritual integrity and dignity and personality of a person and is out of character of international trading business (paragraph 1 of Article 7);

\section{Ways of Loss Compensation due to the Breach of Contractual Liability}

After defining the concept of contractual liability in the international sale contracts convention of goods and Iranian law, it is necessary to be discussed the remedies of damage compensation that may be claimed by the other party resulting from the responsibility attribution to violator.

International sales Convention in both articles 45 and 61 has discussed about executive warranty obligations of the seller and the buyer. These sanctions that are actually a way to compensate the damage of another party, in six cases have been reckoned. Sixth man through compensation can gather with other remedies. This means that lost can request financial payment to its breach of contract in addition to the compensation request of other ways. On the other hand, providing the conditions fulfillment of exemption from liability, this exemption includes only the right of financial request and doesn't include the other means of loss compensation.

Referring to the Iranian civil law and international documents loss compensation practices can be divided into three basic categories that are:

a. The duty to enforce the same obligation

B. Claim for damages

C. Contract termination

It should be noted here that all such means not only apply as a sanction for violation of the transaction, but also they are currently supposed to their health and the absence of legal barriers. In fact, the reason for this is that contract is a coordinated set and everything is included in this collection, will be considered as a part of the contract, whether is in the primary or consequential commitments, "common will" is attached to this synchronous and related organization and composited it totally. Thus, discussions about the conditions of contract is not something apart from and independent of the provisions of the contract (Ghasemi, 2005).

\subsection{Mandatory Implementation of the Contract}

Mandatory implementation of the contract in the proper sense, only include the implementation of the contract, namely the engaged shall do the same provisions of the contract and obligee can request this compulsion and requirement from competent authorities; For example, if engaged does not surrender the goods, the buyer can require him to give up sales from the court, but its mandatory implementation of contracts in general includes the application of substitute goods (second paragraph of article 46 of the Convention) or request for correction or modification of the product (third paragraph of article 46 of the Convention) as well. Request for the mandatory implementation of the contract in its general sense belongs to the buyer, because when a buyer don't implement his commitment, the seller can only request to pay the price when requesting the mandatory implementation of the contract. Because the price in international sale is the cash. In order that the buyer can use this method of compensation (mandatory implementation of the contract), there are limitations, including the buyer is not 
terminated the contract in which with the termination of the contract, the seller gets rid of his related tasks in accordance with the first paragraph of article 81 of the Convention (Jafari Langaroodi, 2008).

The right to request compulsory enforcement of contract by the seller

The buyer has two major tasks that must do: one is the price to pay and another is the bill of goods. When the buyer refuses his obligations, the seller has the right to claim the compulsory execution of the contract in accordance with article 62 of the Convention and this is the Court that make the buyer do his duty. The seller can require mandatory implementation when don't use from other remedies of inconsistent loss compensation with the mandatory implementation; as if had been terminated the contract (article 64). When the goods may loss over time (e.g. perishable goods) and the buyer attempted to not bill it, the Convention gives the seller the right to resell the goods and compensate his damages from this way (article 81, paragraph 1 of the Convention). Using these methods is incompatible with the application of the mandatory contract, because after the termination of the contract or resell the goods by the seller, don't remain any subject to mandatory contracts (Ghasemi, 2005).

Paragraph 1 of article 63 of the Convention gives the buyer a deadline to that time, receipt the goods. The second paragraph of the same article provides that in mentioned period, the seller won't have the right to resort to any means of redress. After the expiry of this deadline, the seller can terminate the contract in accordance with article 64 and if the buyer pays the price within the deadline, the right to terminate of the seller will ruin and basically paying the price by the buyer, the contract will be implemented; But if the buyer does not pay the price in the mentioned deadline, "Seller will not be deprived of any right to claim damages for delay in fulfilling the obligation." (Final part of paragraph 2 of Article 63).

(A) Implementation of the same contract

Implementation of the same contract means that engaged surrender the product to the customer in owned contracts and in covenant contract, he is obliged to follow the provisions of the contract and implement the contract with all the terms and fully, Not that refuses to implement the part of the contract with his choice without previous agreement. Of the first paragraph of article 28 and article 46 of the Convention, which both are about the implementation of the same contract, it can be concluded that the principle of the applicable license is the implementation of the same contract.

(B) Request the surrender of substitute goods

According to the second paragraph of article 46 of the convention, if given goods to the customer wasn't in accordance with the contract and this non-compliance is considered as a fundamental breach, the customer can request submission of the substitute goods from the seller. Of course, in accordance with article 39, customer must already give a notice to the seller based on not having concordance the goods or request the substitute goods to the seller in regular time after it. If the goods are overall and the seller presents non-coincidence goods, in fact, doesn't implement to his contract and the customer can propose the mandatory implementation of the contract in question form of the substitute goods.

\section{(C) Request of product modification or repair}

When the product troubleshooting is possible and the fault is reasonable and standard, if the customer has already given notice of non-compliance, can ask troubleshooting from the salesperson, in cases where faults or defects are negligible, that troubleshooting imposes heavy and unusual costs on the vendor, troubleshooting request is considered unconventional. To determine whether troubleshooting request is conventional or unconventional, must be considered " all circumstances " and according to some commentators must behave in a way that keep benefits of both parties of the contract. This point in context of article 46 of the convention stipulates that: "... if the product is not in conformity with the contract, the buyer can ask the seller to compensate this non-compliance with product repair, unless such a request considered unreasonable considering whole circumstances... the "has come (Katouzian, 2011b).

\subsection{Termination of the Contract}

Article 49 of the convention accounts the items that the buyer can terminate the contract by invoking them want as follows:

(A) When the failure to perform the contract, is accounted basic breach.

(B) Where goods are given in the extra time stipulated by the customer, or vendor declare that cannot surrender the product in determined time.

Direction and overall basis of both cases that is coming at the first paragraph of article 49 of the convention, the idea is "fundamental breach" although it is not mentioned in the second paragraph. Termination of the contract is 
permissible if there is a breach of the contract or engaged refuse to play and give their commitment at the stipulated time, or not being able to do it. In fact, the Convention, the latter is considered the second item as a major violation. What is needed to discuss here is the concept of "fundamental breach"; because with explanation of this idea in the Convention, termination cases can be realized (Huet, 1996).

The concept of fundamental breach

The concept of fundamental breach that is come in Article 49 is explained in Article 29 of the Convention. According to this article, when a breach is fundamental that the first, significant loss imposes to contract party, and secondly, these losses are predictable towards the adversative area. Loss predictability shall exist when the contract conclusion and adversative is responsible for burden of proofing of being unpredictable. In term of basic violation, the concept of fundamental breach can be close to the concept of "major damage". According to this concept, the following cases can be enumerated based on the concept of fundamental breach:

Lack of submission of goods or delaying in it

(B) Refuse to perform the obligation of submission: If before the end of term, engaged announce that does not have the ability to fulfill the obligation, the obligee is entitled to terminate the contract. This meaning is understood from the first paragraph of article 72 of the Convention.

(C) Being impossible of the good submission: Since in the convention, contract's termination is unexpected, so in this case, breach of contract is enumerated basic and can be terminated the contract with announcing.

(D) Submission of the substitute goods: when the product is non- conforming to the contract legally, for example, is claimed by a third party, if the dealer does not act in a reasonable time to correct violations, breach is considered basic and customer has a right to terminate it (Beyanci, 1995).

\section{Compensation for Financial Losses Arising from the Breach of Contractual Obligations}

In principles of international trade contracts after Intituling the lost to receive full compensation, in expression, the intention of full compensation is stipulated that "these damages includes any losses incurred and any benefit that he has been deprived of it." The meaning of "any loss incurred" is expressed in front of the benefits that the lost have been deprived of them; they are direct losses that imposes to lost as a result of non-performing the commitment under the contract. In international sale contracts convention of the goods in article 74 is come "damage caused by the breach of contract by one of the parties is the amount equal to losses, including lack of profit..." According to this article, non-profit that arises with respect to future benefits, is considered as a part of the losses. No doubt, the other parts are the losses that is imposed to obligee.

In Iranian law, such damages are exigible undoubtedly based on contractual liability laws such as article 221 of the civil law and article 515 of the civil Procedure law. Of course, in the article "331" of civil law, some authors believe that such damages can be exigible based on the clause in the causality.

Opinion differences of the principles of the international commercial contracts and the Convention of on the international commodity contracts with Iranian civil law is that loss compensation is absolute based on these two international document and doesn't need to insert a loss compensation clause in the contract, but at the end of article 221 in the civil law, loss compensation depends on this condition "loss compensation stipulates or commitment mean merely stipulation or by law, would be attached." However, in practice, most authors believe that stipulation in the contract is not necessary because in today's business practices, any losses should not be without compensation (Huber, 2007).

\section{Loss Compensation Caused by Being Deprived of Benefits (Non-Profit)}

The actual benefits that are available such as agricultural land and current rent a property, no doubt, is one of the property grandee and is already on the calendar and transferable. And therefore, like other property, there is no doubt in recognition of the factor of losing these benefits. Discussion regarding the benefits is expected; for example, a foreign company is committed to drill 10 oil wells within one year exploit and deliver them. engaged is delayed in performing the contract 1 year and the obligee country is deprived of the expected oil wells a year. These benefits do not exist at the time of contract conclusion; if the commitment is done in accordance with the contract, the beneficiary benefits of their commitment benefits, but engaged does not perform its commitment and obligee will deprive of the expected benefits.

Compensation for damage caused by being deprived of the benefits in principles of the international trade agreements and the Convention of the international commodity contracts

As mentioned, the principles of the international trade agreements in article 7-4-2 knows the lost to deserve the benefits that are deprived of them because of the damages caused by lack of execution. Paragraph 1 of Article 
7-4-2 injury "includes any benefit that he has been deprived of it." .Such as Iran's rights, the deprivation of these interests in the official interpretation of these principles is interpreted to non-profit and has been come "non-profit that is sometimes called consequential losses is a benefit that providing the proper execution of the contract belongs to lost party". Of course, at the end of paragraph 1 of the above article, is stipulated in paying position of damage arising from enhanced benefits, any benefit acquired by the injured party or caused by avoiding the costs must be calculated. Note that if the lost from the face of lack of commitment, earn an interest or as a result of cost avoidance earn an interest should be considered in the loss compensation calculation (Schlechtriem, 1995).

\section{Conclusion}

Although in principle of the need to compensate the loss of breach of the contractual obligations, rights of Iran agree with the principles of the international commercial contracts and the international sale contracts convention of the goods. But in that what items as a damage caused by the breach is exigible, the principles of the international commercial contracts explicitly accepted the theory of receipting the full loss compensation and consider it including the damage as well as damage caused by being deprived of the normal and expected benefits. From the meaning of article 74 of the Convention of the International commodity contracts is used clearly an acceptance of this theory; So from the perspective of these two documents, after compensation, the lost must be placed in a position as if the contract was executed, was in that position. Articles 75 and 76 are pointed to two ways of compensation with the conclusion of the institute transaction and determining the loss based on current prices. Article 77 speaks about the rule dealing with the damage that if the lost waiting for the damage without any conventional action, and does not prevent it, is not entitled to claim it as extent that the damage was preventable. The above regulations that are prepared for the standardization of rules governing on the international sales contracts in addition to help the traders, protects them from the inner laws conflict of the countries.

\section{References}

Badini, H. (2005). Philosophy of civil liability. Tehran, Publishing joint stock Corporation.

Barikloo, A. (2008). Civil liability. Tehran, Mizan Press.

Beyanci, S. M. et al. (1995). The interpretation of international sales rights, translation of Mehrab Darabpour, treasure of knowledge Press, Tehran, p. 86.

Ghasemi, M. (2005). Compensation for breach of contract in the on the International Sale Convention of Goods, the rights of Iran, France, Egypt and Lebanon. Journal of Law, Journal of International Legal Services Office, 1(32), 146.

Honnold, J. (1991). Uniform law for international sales under the 1980 United Nations conversation (7th ed.). Boston.

Huber, P. (2007). The CISG ،A new textbook for student, United States Sellier European Law Publishers.

Huet, J. (1996). Les Principaux Contrats Speciaux, N. 11721. A. P 520, L.G.D.J.

Katouzian, N. (2011a). Civil rights era, the general rules of contract (6th ed., Vol. 4). Tehran, Publishing joint stuck Corporation, pp: 271.

Katouzian, N. (2011b). General rules of contracts, Tehran, Publishing joint stuck Corporation (4th ed., Vol. 3). Pp. 111.

Langaroodi, J., \& Jafar, M. (2008). Terminology rights. Tehran, treasure of knowledge Press.

Safaei et al. (2013). International sales rights with comparative study, vol. 3, pp. 204.

Schlechtriem, P. (1998). Commentary on the UN conversation on the international sale of goods, Translated by G.thomas, Oxford university press. Nicholas B. The United Nations, p 458.

Treitel, G. (2003). Law of contract. London, Sweet \& Maxwell.

\section{Copyrights}

Copyright for this article is retained by the author(s), with first publication rights granted to the journal.

This is an open-access article distributed under the terms and conditions of the Creative Commons Attribution license (http://creativecommons.org/licenses/by/4.0/). 